\title{
Uterine proteins and the activation of embryos from mice during delayed implantation
}

\author{
Hester P. M. Pratt \\ Marshall Laboratory, Physiological Laboratory, University of Cambridge, \\ Downing Street, Cambridge CB2 3EG, U.K.
}

\begin{abstract}
Summary. Ovariectomy-induced delay of implantation was used to study the role of the uterine environment in controlling implantation in mice. Labelling studies in vivo showed that uterine protein synthesis and secretion is maximal $2-5 \mathrm{~h}$ and $24-30 \mathrm{~h}$ after the oestradiol injection which initiates implantation. Embryos removed from uteri 5, 12 or $30 \mathrm{~h}$ after oestradiol injection were able to transport and utilize precursors of nucleic acids and proteins in short-term cultures at the same rate as normal embryos, although 'delayed' embryos had low levels of activity. These results suggest that 'delayed' embryos are metabolically activated within $5 \mathrm{~h}$ of release from delay, perhaps because of the hormonally-induced changes in uterine proteins which occur at this time.
\end{abstract}

\section{Introduction}

During early development, the rodent uterus regulates embryonic metabolism through the two ovarian steroids, oestrogen and progesterone (Psychoyos, 1967). In the nonlactating mouse, the development of the blastocyst takes place in an oestrogen-sensitized uterus (Finn \& Martin, 1972) and results in elevated levels of embryonic RNA synthesis (Daentl \& Epstein, 1971), protein synthesis (Epstein \& Smith, 1973), and other metabolic activities (McLaren, 1973). In a lactating rodent (McLaren, 1968), or one which has been ovariectomized before the endogenous 'oestrogen surge' and the pregnancy maintained with exogenous progesterone (rat: Psychoyos, 1967; mouse: Yoshinaga \& Adams, 1966), the embryos enter an unsensitized uterus and become metabolically quiescent (McLaren, 1968; Weitlauf, 1973, 1974a).

This paper describes an analysis of the interaction, leading to implantation, between the embryo and its uterine environment using the experimentally induced delay of implantation in the mouse (Yoshinaga \& Adams, 1966) as a model system.

\section{Materials and Methods}

Outbred mice of the CFLP strain were induced to superovulate with 10 i.u. PMSG (Folligon: Organon) and $10 \mathrm{i}$.u. HCG (Chorulon: Organon) $48 \mathrm{~h}$ later. CFLP males were used for mating and the day the vaginal plug was found was designated as Day 0.5 post coitum (p.c.). In these mice, embryos enter the uterus on the morning of Day 3.5 and the oestrogen surge occurs in the afternoon, after which the embryos expand and lose their zonae by the morning of Day $4 \cdot 5$. Implantation has begun by the evening of Day 4.5 (Gardner, 1972).

The ovaries were removed under Avertin (Winthrop) anaesthesia, leaving the oviducts intact, before $12.00 \mathrm{~h}$ on Day 3.5. Pregnancy was maintained by subsequent daily s.c. injections of $1 \mathrm{mg}$ progesterone ( $\Delta^{4}$-pregnen-3,20-dione) in arachis oil for 6 days. The implantation process was initiated with one s.c. injection of $50 \mathrm{ng}$ oestradiol benzoate in arachis oil on the following day and would have been complete within $48 \mathrm{~h}$ had not various experiments been carried out as indicated in the 'Results'.

A mixture of ${ }^{14} \mathrm{C}$-labelled amino acids (sp. act. $57 \mathrm{mCi} / \mathrm{milliatom}$ of carbon: Radiochemical Centre, Amersham) or $\left[{ }^{35} \mathrm{~S}\right]$ methionine (sp. act. $50 \mathrm{Ci} / \mathrm{mmol}$ : Radiochemical Centre, Amersham) 
was injected into the lumen of each uterine horn from the ovarian end following exposure of the uterus by a dorsal incision under Avertin anaesthesia. The volume injected was restricted to $3 \mu \mathrm{l} /$ horn.

At autopsy, uteri were flushed with cold sterile phosphate-buffered saline and the fluid centrifuged $(1000 \mathrm{~g}, 15 \mathrm{~min})$, samples not containing embryos being discarded. Endometrial tissue was homogenized at $4^{\circ} \mathrm{C}$ in phosphate-buffered saline and cleared by centrifugation $(5000 \mathrm{~g}, 30 \mathrm{~min})$. When necessary, protein samples were concentrated by precipitation with ethanol, collected by centrifugation and dissolved in the appropriate buffer. Protein content was estimated using the method of Lowry, Rosebrough, Farr \& Randall (1951). Radioactive protein was precipitated and counted as described by Davies \& Hall (1969).

Samples for electrophoresis were reduced with $1 \% \beta$-mercaptoethanol and analysed on sodium dodecyl sulphate (SDS)-polyacrylamide gels calibrated with proteins of known molecular weight (Shapiro, Vinuela \& Maizel, 1967). Gels containing radioactive proteins were cut into $2 \mathrm{~mm}$ slices, solubilized using the techniques of Young \& Fulhorst (1965), and counted in Triton-toluene scintillation fluid (Patterson \& Greene, 1965).

The handling and washing of embryos and extraction of labelled RNA were carried out as described by Daentl \& Epstein (1971). For studies of uridine uptake and incorporation, embryos were cultured in Eagle's basic medium (BME: Flow Laboratories) supplemented with $5 \%$ heat-inactivated and dialysed fetal calf serum. The $\left[5,6-{ }^{3} \mathrm{H}\right]$ uridine (sp. act. $49 \mathrm{Ci} / \mathrm{mmol}$ : Radiochemical Centre, Amersham) was used at a concentration of $50 \mu \mathrm{Ci} / \mathrm{ml}$. The acid-insoluble radioactivity was completely solubilized by hydrolysis with $\mathrm{NaOH}$ or treatment with pancreatic RNAase (Daentl \& Epstein, 1972), and was resistant to hydrolysis with RNAase-free DNAase (Worthington) in the presence of $10 \mathrm{~mm}-\mathrm{MgCl}_{2}$. All radioactivity detected in acid-insoluble material was therefore considered to be incorporated into RNA. For studies of protein synthesis, embryos were incubated with $\mathrm{L}-\left[4,5-{ }^{3} \mathrm{H}\right]-$ leucine (sp. act. $55 \mathrm{Ci} / \mathrm{mmol}$ : Radiochemical Centre, Amersham) at a concentration of $100 \mu \mathrm{Ci} / \mathrm{ml}$ in PBI medium containing $4 \mathrm{mg} \mathrm{BSA} / \mathrm{ml}$ (Whittingham, 1971) and the acid-soluble and insoluble material was isolated as described by Brinster (1971).

\section{Results}

\section{Uterine proteins}

The total protein content of uterine flushings during normal pregnancy in mice is small (Table 1), but the increase after the oestrogen surge which occurs in the afternoon of Day 3.5 continues until Day 5.5 after implantation, when serum proteins are the main constituents of the uterine luminal proteins. Before attempting to relate changes in the luminal protein content to the 'activation' of the embryos, it was necessary to establish whether these proteins were different from those of serum. Plate 1 illustrates the patterns obtained when proteins from uterine secretions of mice with delayed implantation were analysed in SDS-polyacrylamide gels and compared with serum proteins. This procedure separates proteins on the basis of molecular weight and the mobility of a particular protein relative to the dye front is proportional to $\log _{10}$ molecular weight of that protein. Most of the proteins specific to the uterine lumen, i.e. not present in serum, migrate ahead of albumin and therefore have a molecular weight below $70 \times 10^{3}$. This group of fast migrating proteins $(P)$ was present in the uterine flushings of mice throughout delay of implantation and up to $30 \mathrm{~h}$ following administration of oestradiol (Pl. 1, Figs 1-4). By 12-15 h after termination of the delay of implantation with an oestradiol injection, two additional stained bands ( $A$ and $C$ ) with molecular weights of $120 \times 10^{3}$ and $65 \times 10^{3}$ respectively appeared in the uterine flushings and were still present at $30 \mathrm{~h}$ (Pl. 1, Figs 2-4), by which time embryo attachment had begun. These observations suggest that the luminal protein content of the pregnant mouse uterus depends qualitatively and quantitatively on its conditioning by ovarian steroids.

The synthesis and secretion of proteins into the uterine lumen was therefore examined systematically by pulse labelling uteri at various intervals after the oestradiol injection. The results in Table 2 demonstrate that there were two periods of synthesis and/or secretion of uterine proteins at 


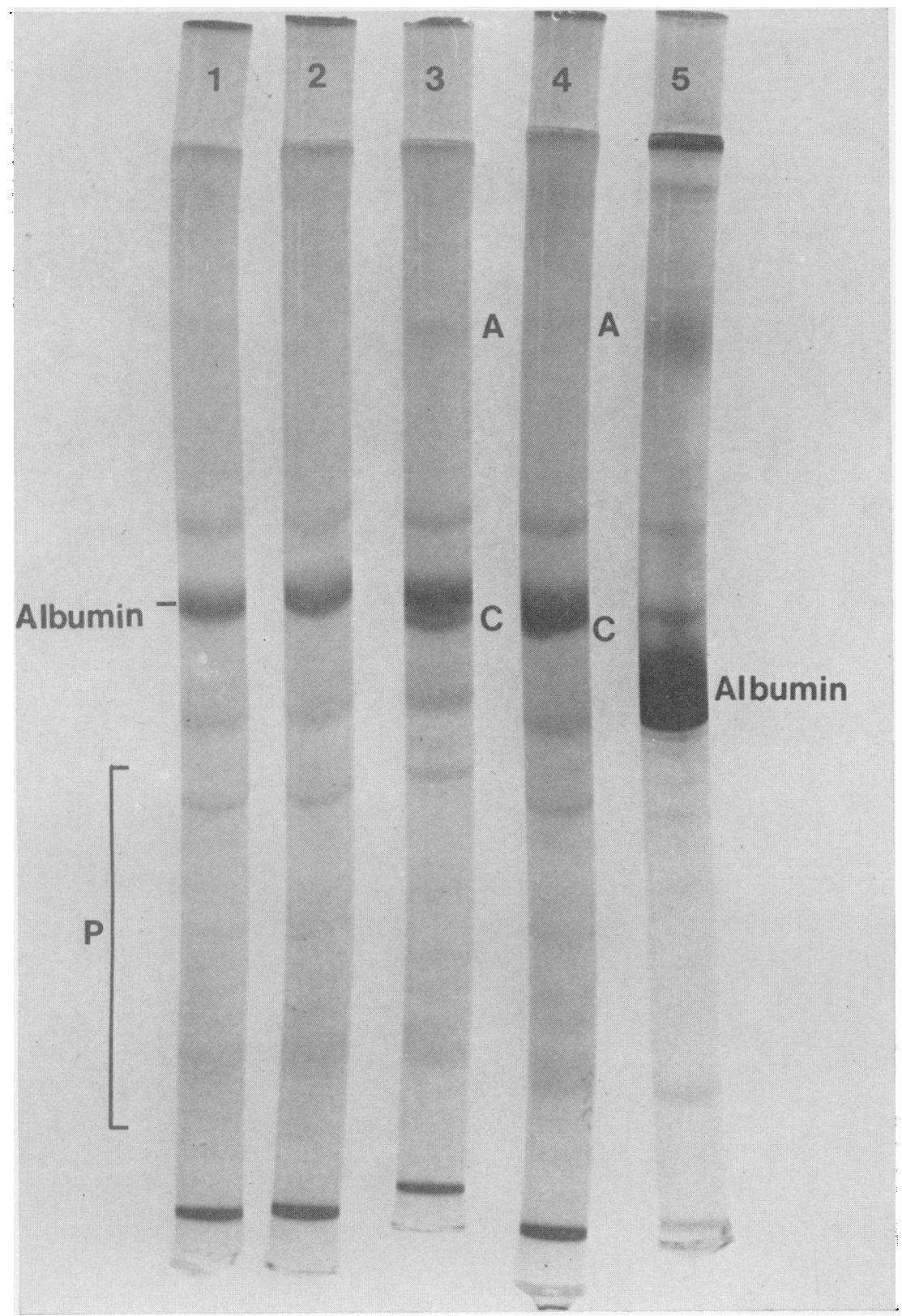

Figs 1-5. SDS-polyacrylamide gels of proteins in the pooled uterine flushings from 6 mice in delay of implantation at various times after initiating implantation with oestradiol treatment. The proteins were labelled with a mixture of ${ }^{14} \mathrm{C}$-labelled amino acids $(0.5 \mu \mathrm{Ci} /$ horn) and each gel was loaded with $150 \mu \mathrm{g}$ protein. The Bands $A$ and $C$ refer to regions incorporating radioactivity (see Text-fig. 1). $P$ refers to the group of uterine proteins with molecular weights below $70 \times 10^{3}$.

Fig. 1. Flushings from animals in delay (no oestradiol).

Fig. 2. Flushings from animals $2 \cdot 5-5 \cdot 0 \mathrm{~h}$ after oestradiol injection.

Fig. 3. Flushings from animals $12 \mathrm{~h}$ after oestradiol injection.

Fig. 4. Flushings from animals $30 \mathrm{~h}$ after oestradiol iniection.

Fig. 5. Normal mouse serum.

(Facing p. 2) 
Table 1. The mean \pm S.E.M. protein content of uterine flushings from non-lactating pregnant mice (at least 5/group)

\begin{tabular}{ccc}
\hline Days post coitum & Hours & Protein content $(\mu \mathrm{g} /$ mouse) \\
\hline Normal & & \\
$2 \cdot 5$ & 20.00 & $33 \pm 6$ \\
3.5 & 20.00 & $18 \pm 5$ \\
4.5 & 12.00 & $28 \pm 4$ \\
4.5 & 20.00 & $54 \pm 6$ \\
5.5 & 09.00 & $125 \pm 13$ \\
'Delay' & & \\
10.0 & 09.00 & $16 \pm 5$ \\
\hline
\end{tabular}

Table 2. The incorporation of $\left.{ }^{35} \mathrm{~S}\right]$ methionine $(2 \mu \mathrm{Ci}$ intraluminally $2 \mathrm{~h}$ before death) into proteins of uterine flushings of mice in delay of implantation at various times after administration of oestradiol

\begin{tabular}{lrrrrrrr}
\hline $\begin{array}{l}\text { Time after oestradiol injection (h) } \\
\begin{array}{c}\text { Acid-insoluble }\left[{ }^{35} \text { S }\right] \text { methionine } \\
\text { (ct/min } \times 10^{-2} \text { per mg protein) }\end{array}\end{array} \quad 510$ & 1400 & 60 & 20 & 50 & 100 & 1080 & 1110 \\
\hline
\end{tabular}

Each value represents the mean for 3 animals.

approximately 2 and $30 \mathrm{~h}$ after injection of oestradiol. Since methionine is a relatively infrequent amino acid, the experiment (see legend to Text-fig. 1) was repeated using ${ }^{14} \mathrm{C}$-labelled amino acids and similar results were obtained. When a short labelling period $(2 \mathrm{~h})$ was used, most of the uterine proteins synthesized and/or secreted into the uterine lumen during delay of implantation had a molecular weight of $70 \times 10^{3}$ and above (see Text-figs $1 \mathrm{a}$ and $1 \mathrm{~b}$, no oestradiol). The group of uterine proteins with molecular weights below $70 \times 10^{3}(\mathrm{P})$ did not incorporate label under these conditions. The major change in the profile of radioactive uterine proteins occurred within $5 \mathrm{~h}$ of administering oestradiol and involved radioactive peaks with the mobilities of Bands $A$ and $C$ (Plate 1). The Band C protein(s) is apparently only synthesized during the first $12 \mathrm{~h}$ after release from delay while Band A protein(s) continues to incorporate label for up to $30 \mathrm{~h}$. Apart from these proteins, another prominent band of radioactivity (Band B: mol. wt approximately $90 \times 10^{3}$ ) was observed in the endometrium but this disappeared after oestradiol treatment. The proteins in Bands A, B and C were shown to be of uterine rather than embryonic origin by their appearance in the uteri of ovariectomized pseudopregnant mice subjected to a similar hormonal regimen.

\section{Metabolism of embryos}

Because release from delay of implantation is associated with changes in the synthesis of uterine proteins, it is possible that these proteins are involved in the activation of the quiescent embryos. Attempts were therefore made to relate some aspects of the metabolism of 'delayed', activated and normal embryos to their respective uterine environments.

Embryos in 'delay' are probably reversibly arrested in the G-1 phase of the cell cycle (Sherman \& Barlow, 1972), and as such exist in an analogous physiological state to cells maintained in vitro under conditions of nutritional deprivation. These embryos might therefore be expected to exhibit a typical pleiotypic response to activation for implantation, e.g. changes in amino acid and nucleoside transport and incorporation (Kram, Mamont \& Tomkins, 1973) followed 24-30 h later by DNA synthesis and mitosis (Todaro, Lazar \& Green, 1965; Sander \& Pardee, 1973). Consequently, these parameters were the ones selected to compare the metabolic activities of the different types of embryos.

A medium which is known to support a degree of postimplantation development was used (Spindle \& Pederson, 1974) and incorporation of $\left[{ }^{3} \mathrm{H}\right]$ uridine into RNA by normal (4.5 days p.c.) 

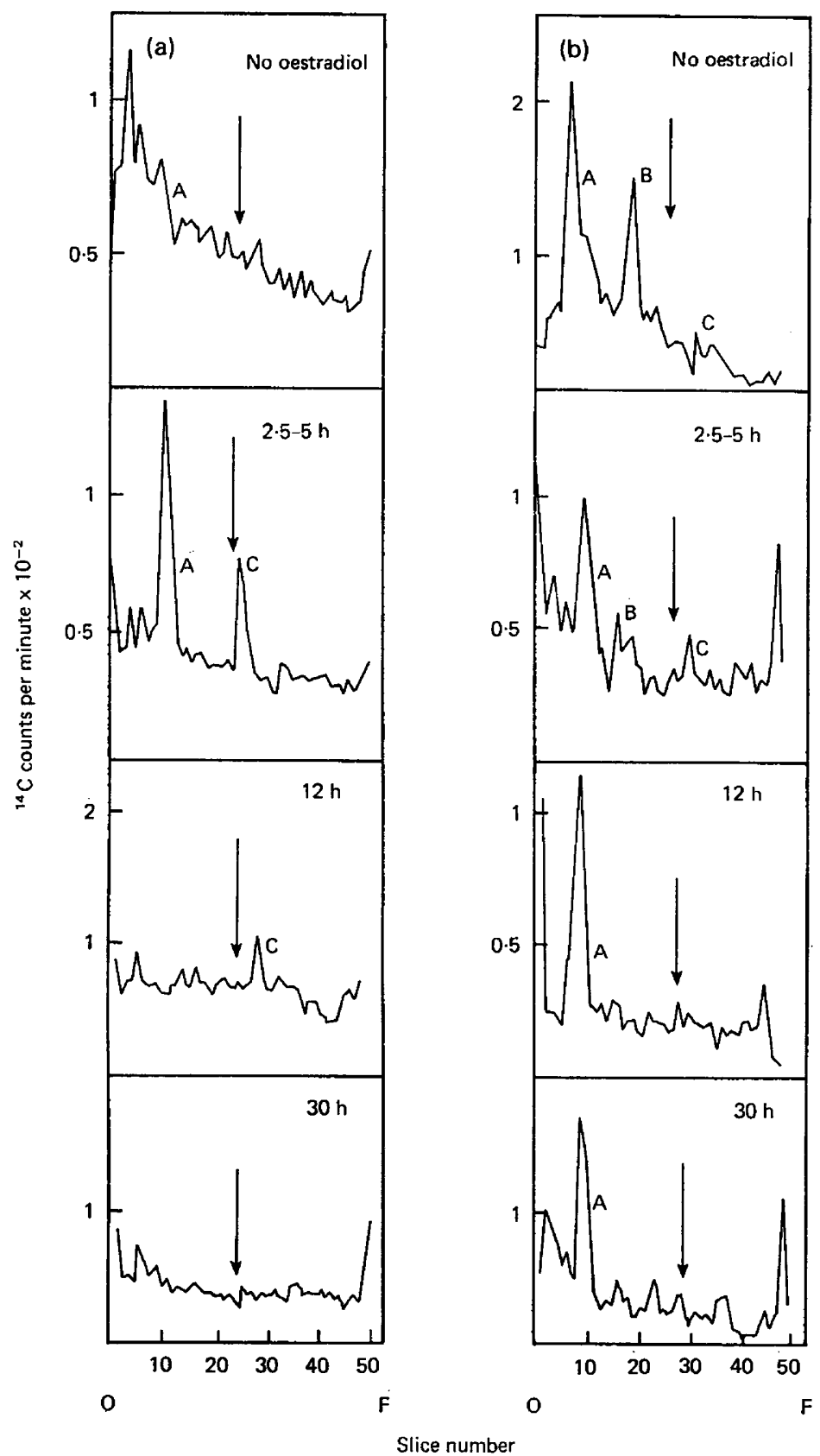

Text-fig. 1. Radioactivity scans of (a) pooled uterine flushings (see Plate 1) and (b) endometrial homogenates of mice in delay of implantation and treated with oestradiol at various times before death. Each pool is represented by 6 mice in (a) and 3 mice in (b). The arrows indicate the mobility of albumin in each gel. $O=$ origin; $\mathbf{F}=$ front. 
Table 3. The uptake (mean \pm S.E.M.) and incorporation of $\left[{ }^{3} \mathrm{H}\right]$ uridine or $\left[{ }^{3} \mathrm{H}\right] l$ leucine into normal, 'delayed' and activated mouse embryos

\begin{tabular}{|c|c|c|c|c|c|}
\hline \multirow[b]{2}{*}{ Embryos } & \multirow[b]{2}{*}{$\begin{array}{l}\text { Incubation } \\
\text { time (h) }\end{array}$} & \multicolumn{2}{|c|}{$\left[^{3} \mathrm{H}\right]$ uridine* } & \multicolumn{2}{|c|}{$\left[{ }^{3} \mathrm{H}\right]$ leucine $\dagger^{-}$} \\
\hline & & $\begin{array}{c}\text { Total uptake } \\
\text { (pmol/embryo) }\end{array}$ & $\begin{array}{l}\text { Incorporation } \\
\text { (pmol/embryo) }\end{array}$ & $\begin{array}{c}\text { Total uptake } \\
\text { (pmol/embryo) }\end{array}$ & $\begin{array}{l}\text { Incorporation } \\
\text { (pmol/embryo) }\end{array}$ \\
\hline \multirow[t]{2}{*}{ Normal } & 4 & $0.327 \pm 0.005$ & 0.0361 & $0.150 \pm 0.009$ & 0.0765 \\
\hline & 24 & $0.633 \pm 0.008$ & 0.0776 & $0.235 \pm 0.008$ & $0 \cdot 1090$ \\
\hline \multirow[t]{2}{*}{ Delayed (untreated) } & 4 & $0.159 \pm 0.009$ & 0.0079 & $0.012 \pm 0.001$ & 0.0010 \\
\hline & 24 & $0.749 \pm 0.060$ & 0.0821 & $0.130 \pm 0.005$ & 0.0600 \\
\hline \multicolumn{6}{|l|}{ Delayed (activated) } \\
\hline $5 \mathrm{~h}$ & 4 & $0.296 \pm 0.006$ & 0.0267 & $0.210 \pm 0.002$ & $0 \cdot 0018$ \\
\hline $12 \mathrm{~h}$ & 4 & $0.272 \pm 0.020$ & 0.0270 & $0.248 \pm 0.030$ & 0.0012 \\
\hline $30 \mathrm{~h}$ & 4 & $0.279 \pm 0.030$ & 0.0320 & $0.299 \pm 0.040$ & 0.0027 \\
\hline
\end{tabular}

Mice with delay of implantation ( 10 day p.c.) were given either $1 \mathrm{mg}$ progesterone (untreated group) $5 \mathrm{~h}$ before death or $1 \mathrm{mg}$ progesterone $+50 \mathrm{ng}$ oestradiol (activated group) 5,12 or $30 \mathrm{~h}$ before being killed and the embryos removed. Embryos (normal) were also obtained from intact mice on the morning of Day 4.5 p.c. Values were obtained from three experiments in which embryos were assayed in duplicate in groups of 5-10.

$* 0.1 \mathrm{pmol}$ uridine represents $1.9 \times 10^{3} \mathrm{ct} / \mathrm{min}$ detected.

$\dagger 0.1 \mathrm{pmol}$ leucine represents $2.4 \times 10^{3} \mathrm{ct} / \mathrm{min}$ detected.

embryos was linear for up to $6 \mathrm{~h}$ and was independent of total uptake at the concentration of precursor used $(1.3 \mu \mathrm{M})$. Table 3 demonstrates that after $4 \mathrm{~h}$ in culture the total uptake of uridine and its incorporation into RNA by normal embryos was substantially greater than for 'delayed implanting' embryos. However, after $24 \mathrm{~h}$ of culture the activity of the two types of embryo was similar. When $\left[{ }^{3} \mathrm{H}\right] \mathrm{leucine}$ uptake and incorporation into protein by 'delayed' and normal embryos was compared, the 'delayed' embryos were substantially less active than normal 4.5 day embryos (Table 3), but their activity increased after prolonged incubation, indicating that any repressive uterine influence on the delayed embryos had been overcome and resulted in activation of nucleic acid and protein synthesis similar to that of normal embryos. Short-term incubations are therefore necessary to detect metabolic differences between embryos.

To observe the effects of initiating implantation in vivo, embryos were removed from the uteri of mice in delay at 5, 12 and $30 \mathrm{~h}$ after injecting the mother with oestradiol and their metabolic activity was compared with that of unstimulated 'delayed' embryos and normal embryos (Table 3 ). The activated embryos behaved similarly regardless of the time spent in the uterus before incubation. The uptake and incorporation of leucine and uridine approached that of normal $4 \cdot 5$ day p.c. embryos within $5 \mathrm{~h}$ of the oestradiol injection.

\section{Discussion}

These experiments have confirmed the existence of proteins specific to the uterine lumen of the mouse (Mintz, 1970) and demonstrated changes in these macromolecules following the induction of implantation. Changes in uterine components during early pregnancy and the oestrous cycle have been observed in other species including the rabbit (Daniel, 1968), pig (Murray, Bazer, Wallace \& Warnick, 1972), and man (Shirai, Iizuka \& Notake, 1972). A steroid-binding function has been suggested for the progesterone-dependent rabbit protein, uteroglobin (Arthur, Cowan \& Daniel, 1972; Fowler, Johnson, Walters \& Pratt, 1976), but the function of the other uterine proteins and their possible roles in maintaining the development of the embryos remain obscure. It has been shown that uterine control is not operating at the level of availability or restriction of simple nutrients during this period (Weitlauf, 1968, 1971) and therefore the proteins that appear in the flushings after the initiation of implantation could be involved in controlling embryonic growth.

Since the cells of a diapausing embryo are probably arrested in the G-1 phase of the cell cycle (Sherman \& Barlow, 1972) as are other non-dividing cells (Costlow \& Baserga, 1973), it is possible 
that the stimulus to implant is associated with a transition to the $\mathrm{S}$ phase (DNA synthesis). This is likely to result in increased transport and incorporation of nucleosides and amino acids similar to those induced by mitogenic stimulation or serum repletion in a variety of cell types (Sander \& Pardee, 1973). Although the absence of data on endogenous pool sizes makes it difficult to compare the different types of embryos, previous autoradiographic studies of normal and 'delayed' embryos have confirmed in-vitro observations to be a true indication of the activity of such embryos in vivo (Weitlauf, 1971). In addition, the extent of uptake and incorporation of precursors into RNA and protein by normal preimplantation embryos is comparable to the values reported in previous studies using similar assay conditions (Brinster, 1971; Daentl \& Epstein, 1972). Differences in incorporation of leucine and uridine in vitro after short culture periods are therefore taken to be indicative of a true difference in metabolic activity between diapausing and normal embryos. Activity is expressed on a per embryo basis in this paper, though mitosis may continue in some cells of 'delayed' embryos, resulting in an increase of approximately $20 \%$ over the total cell number in normal embryos (McLaren, 1968; Sherman \& Barlow, 1972).

To understand the control of implantation, it must be determined whether embryonic activity is regulated directly by the ovarian steroids and, if not, how their effect is mediated through the uterus. The experiments described here do not completely exclude the possibility that steroids may be having a direct effect on embryos in vivo or in vitro (Smith \& Smith, 1972; Lau, Davis \& Chang, 1973). However, for the in-vitro experiments, steroid contamination was kept as low and as uniform as possible by washing all embryos three times in flushing medium and using a single batch of fetal calf serum after extensive dialysis. Under these conditions, 'delayed' embryos required more than $4 \mathrm{~h}$ incubation before uptake and incorporation of uridine increased to normal $4 \cdot 5$ day p.c. levels (Table 3 ). This lag for optimal RNA synthesis in vitro only occurred in 'delayed' embryos and has been reported by others (Psychoyos \& Bitton-Casimiri, 1969; Weitlauf, 1974b). It is also associated with increased $\mathrm{CO}_{2}$ production (Menke \& McLaren, 1970) and the ability to resume proliferation (Gwatkin, 1966). All these activities are dependent upon a non-dialysable component(s) of fetal calf serum and its omission from the medium leads to resumed quiescence of the embryos. It therefore appears that after the oestrogen surge the uterus provides the same growth-enhancing environment as a serumcontaining medium, and maintenance of the 'delayed' condition is due to absence of these growth stimuli.

The results of the experiments involving activation of embryos in vivo support this idea. Permeability and synthetic changes are established within $5 \mathrm{~h}$ of priming with oestradiol (Table 3 ). The incorporation of uridine into embryonic RNA, detected in utero by autoradiography, increases within $1 \mathrm{~h}$ of administering oestradiol to 'delayed implanting' rats and is maintained for up to $18 \mathrm{~h}$ (Dass, Mohla \& Prasad, 1969). The increase in metabolic activity observed in vitro occurs without the $4 \mathrm{~h}$ lag period observed for 'delayed' embryos (Table 3 ). This interval could represent the $4 \mathrm{~h}$ preactivation period demonstrated in the experiments of Weitlauf $(1973,1974 b)$, and the absence of such a lag period for embryos activated in vivo suggests that the necessary metabolic changes take place in response to the oestradiol treatment before removal of the embryos from the uterus.

Factors responsible for the activation of preimplantation embryos could be steroids (probably in the form of steroid-protein complexes) or proteins or glycoproteins acting in a similar manner to that of mitogenic lectins or polypeptide hormones. It is difficult to exclude the influence of steroids in in-vivo or in-vitro experiments. However, the observation that 'delayed' embryos undergo similar metabolic changes after activation in vivo or in vitro suggests that the factors responsible are growthpromoting proteins or glycoproteins similar to those already isolated from serum (Holley, 1974). Since the metabolic activation of 'delayed' embryos $5 \mathrm{~h}$ after oestrogen administration in vivo occurs in association with a major change in the profile of uterine proteins, it seems worthwhile investigating whether these uterine proteins (either alone or as steroid-protein complexes) have any direct regulatory influence on embryonic growth.

This work was supported by a grant from the Sybil Eastwood Memorial Trust, Cambridge, and a grant from the Ford Foundation to Professor C. R. Austin. I thank Dr A. Surani and Dr M. H. Johnson for helpful discussions. 
References

Arthur, A.T., Cowan, B.D. \& Daniel., J.C. (1972) Steroid binding to blastokinin. Fert. Steril. 23, 35-91.

Brinster, R.L. (1971) Uptake and incorporation of amino acids by the preimplantation mouse embryo. J. Reprod. Fert. 27, 329-338.

Costlow, M. \& Baserga, R. (1973) Changes in membrane transport function in $G_{0}$ and $G_{1}$ cells. J. cell. Physiol. 82, 411-420.

DaEnTL, D.L. \& EpsTein, C.J. (1971) Developmental interrelationships of uridine uptake, nucleotide formation, and incorporation into RNA by early mammalian embryos. Devl Biol. 24, 428-442.

DANIEL, J.C. (1968) Comparative electrophoretic patterns of uterine fluids of rabbits and mammals having delayed implantation. Comp. Biochem. Biophys. 24, 297-304.

Dass, C.M.S., Mohla, S. \& Prasad, M.R.N. (1969) Time sequence of action of oestrogen on nucleic acid and protein synthesis in the uterus and blastocyst during delayed implantation in the rat. Endocrinology 85, 528-536.

Davies, J.W. \& Hall, A. (1969) Liquid scintillation counting methods for accurate assay of $\beta$-radioactivity in biological experiments. Analyt. Biochem. $27,77-90$.

Epstein, C.J. \& Smith, S.A. (1973) Amino acid uptake and protein synthesis in preimplantation mouse embryos. Devl Biol. 33, 171-184.

FINN, C.A. \& MARTIN, L. (1972) Endocrine control of the timing of endometrial sensitivity to decidual stimulus. Biol. Reprod. 7, 82-86.

Fowler, R.E., Johnson, M.H., WAlters, D.E. \& PRATT, H.P. (1976) The progesterone and protein composition of rabbit uterine flushings. J. Reprod. Fert. 46, 427-430.

GaRDNER, R.L. (1972) An investigation of inner cell mass and trophoblast tissues following their isolation from the mouse blastocyst. J. Embryol. exp. Morph. 28, 279-292.

GwatkIN, R.B.L. (1966) Amino acid requirements for attachment and outgrowth of the mouse blastocyst in vitro. J. cell. Physiol. 68, 335-344.

Holley, R.L. (1974) Serum factors and growth control. In Control of Proliferation in Animal Cells, pp. 13-18. Eds B. Clarkson \& R. Baserga. (Cold Spring Harb. Conf., Cell Prolif.)

Kram, R., Mamont, P. \& Tomkins, G.M. (1973) Pleiotypic control by adenosine $3: 5^{\prime}$-cyclic monophosphate: a model for growth control in animal cells. Proc. natn. Acad. Sci. U.S.A. 70, 1432-1436.

LaU, N.I.F., Davis, B.K. \& Chang, M.C. (1973) Stimulation of in vitro ${ }^{3} \mathrm{H}$-uridine uptake and RNA synthesis in mouse blastocysts by $17 \beta$-estradiol. Proc. Soc. exp. Biol. Med. 144, 333-336.

Lowry, O.H., Rosebrough, J.J., Farr, A.L. \& RANDALL, R.J. (1951) Protein measurement with the Folin phenol reagent. J. biol. Chem. 193, 265-275.

MCLAREN, A. (1968) A study of blastocysts during delay and subsequent implantation in lactating mice. J. Endocr. 42, 453-463.
MCLAREN, A. (1973) Blastocyst activation. In Regulation of Mammalian Reproduction, pp. 321328. Eds S. S. Segal, R. Crozier, P. A. Corfmann \& P. G. Condliffe. C. C. Thomas, Springfield, Illinois.

Menke, T. M. \& Mclaren, A. (1970) Mouse blastocysts grown in vivo and in vitro: carbon dioxide production and trophoblast outgrowth. J. Reprod. Fert. 23, 117-127.

Mintz, B. (1970) Control of embryo implantation and survival. Adv. Biosci. 6, 317-340.

MurRay, F.A., Bazer, F.W., Wallace, H.D. \& WARNICK, A.C. (1972) Quantitative and qualitative variation in the secretion of protein by the porcine uterus during the estrous cycle. Biol. Reprod. 7, 314-320.

Patterson, M.S. \& Greene, R.C. (1965) Measurement of low energy emitters in aqueous solution by liquid scintillation counting of emulsions. Analyt. Chem. 37, 854-857.

Psychoyos, A. (1967) Hormonal interplay controlling egg implantation in the rat. Adv. Reprod. Physiol. 2, 257-277.

Psychoyos, A. \& Bitton-Casimiri, B. (1969) Captation in vitro d'un précursor d'acide ribonucleique (ARN) (uridine-5- ${ }^{3} \mathrm{H}$ ) per le blastocyste du rat; différences entre blastocystes normaux et blastocystes en diapause. C.r. hebd. Séanc. Acad. Sci., Paris 268, 188-194.

Sander, G. \& Pardee, A.B. (1973) Transport changes in synchronously growing $\mathrm{CHO}$ and $\mathrm{L}$ cells. $J$. cell. Physiol. 80, 267-272.

ShapiRo, A.L., Vinuela, E.D. \& Maizel, J.V. (1967) Molecular weight estimation of polypeptide chains by electrophoresis in sodium dodecyl sulphate polyacrylamide gels. Biochem. Biophys. Res. Commun. 28, 815-820.

Sherman, M.I. \& Barlow, P.W. (1972) DNA content in delayed mouse blastocysts. J. Reprod. Fert. 29, 123-126.

Shirai, E., Iizuka, R. \& Notake, Y. (1972) Analysis of human uterine fluid protein. Fert. Steril. 23, 522-527.

Smith, D.M. \& SMITH, A.E.S. (1971) Uptake and incorporation of amino acids by cultured mouse embryos. Estrogen stimulation. Biol. Reprod. 4, 66-73.

SpIndle, A.I. \& Pederson, R.A. (1974) Hatching, at tachment and outgrowth of mouse blastocysts in vitro. Fixed nitrogen requirements. $J$. exp. Zool. 186, 305-318.

Todaro, G.J., Lazar, G.K. \& Green, H. (1965) The initiation of cell division in a contact inhibited mammalian cell line. J. cell. Physiol. 66, 325-334.

WeITLAUF, H.M. (1968) Influence of estrogen and progesterone on the incorporation of ${ }^{35} \mathrm{~S}$-methionine by blastocysts in ovariectomized mice. J. exp. Zool. $169,463-470$.

Weitlauf, H.M. (1971) Protein synthesis by blastocysts in the uteri and oviducts of intact and hypophysectomized mice. J. exp. Zool. 176, 35-40, 
WeITLAUf, H.M. (1973) In vitro uptake and incorporation of amino acids by blastocysts from intact and ovariectomized mice. J. exp. Zool. 183, 303-308.

WeITLAUP, H.M. (1974a) Metabolic changes in the blastocysts of mice and rats during delayed implantation. J. Reprod. Fert. 39, $213-224$.

WeIrLauF, H.M. (1974b) Effect of actinomycin D on protein synthesis by delayed implanting mouse embryos in vitro. J. exp. Zool. 189, 197-202.
WhItTINGHAM, D.G. (1971) Culture of mouse ova. J. Reprod. Fert., Suppl. 14, 7-21.

YoshinAGA, K. \& ADAMs, C.E. (1966) Delayed implantation in the spayed progesterone treated adult mouse. J. Reprod. Fert. 12, 593-595.

YounG, R.W. \& Fulhorst, H.W. (1965) Recovery of ${ }^{35} \mathrm{~S}$ radioactivity from protein bearing polyacrylamide gel. Analyt. Biochem. 11, 389391.

Received 29 May 1976 